\section{Mediating effect of strategy on competitive pressure, stakeholder pressure and strategic performance management (SPM): evidence from HEIs in Indonesia}

\author{
Noorlailie Soewarno and Bambang Tjahjadi \\ Department of Accounting, \\ Faculty of Economics and Business, Universitas Airlangga, Surabaya, Indonesia
}

Mediating effect of strategy

\begin{abstract}
Purpose - This study aims to explore the mediating role of strategy. First, we examine whether strategy mediates the relationship between competitive pressure and SPM. Second, we examine whether the strategy mediates the relationship between stakeholder pressure and SPM.

Design/methodology/approach - This study is designed as a quantitative study by utilizing partial least squares structural equation modeling (PLS-SEM) in order to test the hypotheses. A mediation model for the research framework was developed to investigate the mediating role of strategy.

Findings - Using a sample of 546 managers from higher education institutions (HEIs) in Indonesia, the results show that both competitive pressure and stakeholder pressure have a positive direct effect on SPM. Strategy fully mediates the relationship between competitive pressure and SPM and strategy also partially mediates the relationship between stakeholder pressure and SPM. The findings suggest that the management of the HEIs in Indonesia needs to accommodate the dynamic trends in the competitive environment and the stakeholder's interests when they develop the strategy used. They need to build a reliable SPM to effectively execute the strategy.
\end{abstract}

Research limitations/implications - This study has the following limitations: (1) the use of PLS-SEM may raise the issue of causality; (2) this study focuses only on the antecedents of the SPM, and therefore future studies should investigate the consequences of the SPM on other variables; (3) this study is context-specific for Indonesia and caution should be used when generalizing it to other countries; (5) this study employs the primary data that may raise the issue of perception bias, and therefore future studies should try to develop proxies of variables using secondary data.

Practical implications - This research provides a comprehensive understanding of the management of HEIs who wants to enhance their SPM. This suggests that management needs to verify the role of strategy. In the era of global competition in higher education, management needs to start from the dynamics of competitive intensity and stakeholder interest. Competition and cooperation need to be considered in their strategies if they want to survive in the higher education industry. Finally, management must be aware that they are now assessed using quantitative indicators, standardized processes, and algorithms, and therefore they need to have a more reliable SPM.

Social implications - As the global competition increases in higher education, this research provides a model on how to improve the good university governance involving the strategy and the SPM. Higher education plays an extremely important role in society. This study provides a model that can be used by society to have better control of the HEIs by demanding improved good governance. This research provides empirical evidence of the importance of the strategy and the SPM. The society will get more benefits in terms of improved transparency, accountability, fairness, and responsibility of the HEIs.

Originality/value - This is the first study that explores the links between competitive pressure, stakeholder pressure, strategy and SPM in Indonesian HEIs. It provides empirical evidence in the HEIs research setting for

The authors thank the Director General of Institution, Research and Technology, and Higher Education, the Ministry of Technology Research and Higher Education, the Republic of Indonesia for facilitating us during the data gathering.

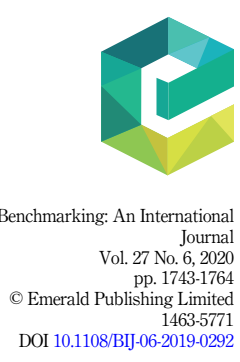


BIJ

27,6

the industry/organization (I/O) theory of competitive advantage which focuses on the external factors. It also supports the resource-based view (RBV) model of competitive advantage which focuses on internal factors.

Keywords Competitive pressure, Stakeholder pressure, Strategy, Strategic performance management, Higher education institutions

Paper type Research paper

\section{Introduction}

In the digital era of knowledge economy, higher education plays a more critical role than ever. Competence in terms of both human capital and advanced technology have transformed education for the good of society (Rosenbusch, 2020). Today, the welfare of society depends more on intangible assets rather than tangible resources. The fact that the oil-rich countries in the Middle East have been struggling to reduce their dependence on oil and that they are beginning to focus on human resource development proves that human capital is the key to a better future welfare (Budhwar et al., 2018). As stated by Kaur et al. (2019), the key to organizational performance in this dynamic world also depends on an ambidextrous and dynamic adjustment approach focusing on a balance between continuity and strategic change. Advanced technology such as cognitive computing can help to integrate the information and knowledge required for both operational and strategic decisions. Following Kaur et al. (2019), an ambidextrous HEIs must be agile, ready to change and have strong predictive capabilities. HEIs will need more advanced good governance as a result.

Good governance has become a big issue in society because it has a positive impact on performance (Nicholson and Kiel, 2007; Bhagat and Bolton, 2009; Azeez, 2015; Hussain et al., 2018; Mutlu et al., 2018). The existence of a sound strategy is crucial in a good governance process. Good governance and strategy require a solid management control system for both diagnostic and interactive uses (Arjaliès and Mundy, 2013; Frezatti et al., 2017). One of the crucial elements of management control is SPM, which is the focus of this study.

SPM arises because the management needs more strategic and comprehensive information regarding strategy monitoring and feedback during strategy execution. This kind of information is not provided by a budget-based performance management system. Due to the growth of its importance, scholars have explored the strategic factors affecting management control systems including SPM (Simons, 1991; Kaplan and Norton, 2007; Adler et al., 2017). Other studies have provided more empirical evidence on the influence of the other factors on the performance management system, such as behavioral factors (Elzinga, 2009), organizational factors (Mansor et al., 2012) and internal as well as external factors (Jelínková, 2017). However, there has not yet been a study exploring the mechanism of how strategy affects the competitive pressure-SPM relationship as well as the stakeholder pressure-SPM relationship using a mediation model of the research framework, especially in the context of the HEIs in Indonesia as a developing country.

Global competition triggers the need for better good governance. In an increasingly competitive environment, an organization needs to have a good strategy in order to create value to get a competitive advantage (Otley, 1999; Friis et al., 2016; Hernández-Perlines et al., 2016). Industrial/organization (I/O) theory and resource-based view (RBV) are the two theories that dominate the explanation of competitive advantage (Barney, 1991; Conner, 1991; Wernerfelt, 1995; Popli et al., 2017). The I/O theory explains that the external environment is the primary determinant of the strategies that firms select in order to be successful (Conner, 1991; Hosskisson et al., 1999; Albert and Hilderbrand, 2016; Amor et al., 2018). The industry or segment of the industry has a stronger influence on performance than what the managers can do inside their organizations (Bowman and Helfat, 2001; Hawawini et al., 2002). The resource-based view (RBV) assumes that each organization is a collection of unique resources and capabilities, and therefore the uniqueness is the basis of its strategy and ability to a achieve competitive advantage (Penrose, 1959; Barney, 1991; Wernerfelt, 1984; Newbert, 
2008; Alexy et al., 2018). Innovation, especially an open innovation capability, is a crucial resource for building a competitive advantage because it relates to the flow of knowledge across an organization's frontiers. It synchronizes with the organization's business model (Chesbrough, 2017; Singh et al., 2019a, b).

Competition and competitive advantage relate to organizational strategy (Elkin et al., 2008; Gabrielsson et al., 2016; Bakoğlu et al., 2016). Porter (1986) stated that the essence of strategy is choosing to perform activities differently than their rivals do. The management needs to choose a different set of activities to deliver a unique value. Therefore, competitive pressure relates to the organizational strategy used in order to achieve a competitive advantage (Slivko and Theilen, 2013; Dupire and M'Zali, 2016; Kadhim et al., 2018).

In higher education, global competition has also been occurring. Previous studies have proven that the competitive intensity among HEIs has been significantly increasing (Marginson, 2006; Hasse and Krucken, 2013; Bagley and Portnoi, 2014; Pucciarelli and Kaplan, 2016; Musselin, 2018). A study conducted by Ho and Peng (2016) showed that the dynamics of the changes taking place in the global education environment contribute to the increasing competition between universities in Taiwan. This global trend is also entering Indonesia, which has about 4,674 HEIs concentrated in the big cities. This increasing competitive pressure requires the management of the HEIs to develop strategies as a unique way to achieve competitive advantage. The World Class University (WCU) rankings by the QS (Quacquarelli Symonds) and THE (Times Higher Education) have driven the management of the HEIs in Indonesia to engage in competitive behaviors for the sake of their quality and reputation. The management is also continuously demanded to better understand how to improve performance and how to consistently outperform other institutions. Following the statement of Taylor et al. (2013), the educational pattern in Indonesia has also been transformed from the education of the elite to the education of the masses.

In addition to the pressure from competitors, the HEI is also pressured by their stakeholders. Stakeholder theory states that the performance of an organization relates to having a highly ethical relationship with its stakeholders, characterized by high levels of trust, cooperation and information sharing (Donaldson and Preston, 1995; Schaltegger et al., 2017; Jones et al., 2018). Stakeholders demand that the management implement good governance in which the management control system is one of the important elements. The stakeholders of the HEIs, such as students, employers, employees, alumni, parents, donors and government institutions, require the management to implement sound strategies to safeguard their interests. Previous studies have shown that there is a positive association between the stakeholders and the strategy used (Frooman, 1999; Sharma; Henriques, 2004; Li; et al., 2017), as well as a positive association between the stakeholders and the management control system (Annosi et al., 2017; Barnett et al., 2018).

Both competitive pressure and stakeholder pressure must be considered by the management when they develop organizational strategies. To effectively execute these strategies, the management needs to design and implement a solid system of management control, especially SPM, in order to guarantee that the managers act in line with the direction of the strategy. In other words, SPM is needed to avoid the dysfunctional behavior among the managers (Soobaroyen, 2005; Cugueró-Escofet and Rosanas, 2017; Fiolleau et al., 2017).

This study chose Indonesia because of its uniqueness and due to the complexity of the country compared to other countries. First, regarding the geographical aspect, Indonesia is an archipelago with more than 17,000 islands. With a total sea area of 5.9 million square kilometers, Indonesia is the largest archipelago in the world. Second, referring to the social and cultural aspects, Indonesia has 1,340 ethnic groups and 718 local languages (Welianto, 2020; Jambi-independent.co.id, 2019). Fortunately, Indonesia has Bahasa as a unifying language. Third, regarding the economic aspect, Indonesia's economic structure is still based 
BIJ

27,6

1746

on natural resources and an uneven development between one island and another. Fourth, Indonesia has a population of 265 million people, making Indonesia the fourth most populous country in the world after China, India and the United States. Fifth, according to the 2019 Human Development Index report released by the United Nations (1982), Indonesia ranks 111th out of 189 countries (world.tempo.co). Human resource development is the government's top priority. Finally, as revealed by Berenschot and Mulder (2019), the quality of the local government in Indonesia is related to clientelistic practices and the state dependency on the local economies. Indonesia is also a country in Southeast Asia that has increased its level of corporate governance significantly (Latan et al., 2016). A study by Latan et al. (2018) revealed that the increased corporate governance in Indonesia is indicated by a significant relationship between the components of the whistle-blowing triangle and the intention of blowing the whistle. Given the uniqueness and complexity of the potential political, economic, socio-cultural, technological and environmental problems that can arise, it is interesting to test our research model for competitive pressure, stakeholder pressure, strategy and performance management in the Indonesian HEI research setting.

In the area of higher education, Indonesia has 4,687 HEIs in several legal forms consisting of 586 universities, 221 institutes, 2,538 higher schools/colleges, 1,063 academies and 279 polytechnics (PDDIKTI, 2019). The competition among the HEIs in Indonesia is driven by the Ministry of Research, Technology and Higher Education (the MRTHE). The MRTHE develops internal competitive schemes to compare and rank individual researchers and the HIEs themselves. In addition to internal competitive schemes, the MRTHE also follows the WCU classification based on the QS and the THE. As a result, the HEIs in Indonesia are now assessed using standardized processes, algorithms and quantitative indicators. Therefore they are more visible and easier to compare.

By focusing on the need for transformation in higher education, this study departs from the previous work of existing scholars. It is inspired by the work of Musselin (2018) stating that new forms of competition in higher education have improved the university governance by increasing the level of autonomy and introducing management practices developed in private firms. The present study focuses on elaborating on the issue by analyzing and testing the roles of strategy and SPM as the result of pressure from both competitors and stakeholders in the Indonesian HEIs.

The objective of this study is to analyze and test the mediation model of a research framework involving strategy within the relationship between competitive pressure, stakeholder pressure and SPM. As previously discussed, the previous studies have been done by scholars to test the direct associations between competitive pressure and strategy, stakeholder pressure and strategy as well as the strategy and management control system. However, researchers have only rarely conducted studies on the antecedents of SPM using a mediation model, especially in the HEI research setting. This study argues that the antecedents of SPM are strategy, competitive pressure and stakeholder pressure in which strategy plays a mediating role in the research model. This study is also the first research that explores the mechanism of how the strategy links competitive pressure and stakeholder pressure to the SPM used by the Indonesian HEIs.

This study has the following contributions. First, it focuses on investigating the mediating role of strategy and it therefore contributes to the resource-based view, especially in the area of strategy formulation and execution. It also leads to the understanding that the management of HEIs in Indonesia need to develop SPM that will provide more comprehensive information compared to the information provided by the budget-based performance management system. Second, it explores the importance of recognizing competitive pressure and stakeholder pressure as the antecedents of SPM, therefore contributing to the I/O theory of competitive advantage and stakeholder theory. Finally, while most of the previous studies have been conducted in developed countries, this study 
focused on exploring the antecedents of SPM in the HEIs in a developing country, particularly Indonesia. This will help the management of the HEIs in Indonesia to understand that they need to accommodate these pressures when they develop a new strategy. They need to design and implement SPM in order to improve the quality of the management control and the strategy execution.

The next section of this paper will describe the "literature review and hypotheses development," followed by the "research methodology." Furthermore, the section on the "results and discussion" will be presented. Finally, the last section describes the "conclusions, contributions and further research."

\section{Literature review and hypotheses development}

The competition in higher education has been impressively changing and transforming. Musselin (2018) stated that competition in higher education is “. . . a form of conflict and rivalry, wherein different parties target the same faculty, the same students and the same funding for their projects, or different parties are voluntarily or involuntarily participating in ranking, rating and evaluation exercises.”

The competition in higher education is no longer occurring between individuals and countries. It has become institutional, leading to a multi-level forms of competition that have transformed universities into competitors (Musselin, 2018). The most successful institutions are no longer engaged in a national contest; they compete globally (Slaughter and Leslie, 1997; Lazega and Snijders, 2016; Musselin, 2018). The studies by Musselin et al. (2014) and Chatelain-Ponroy et al. (2012) on university leaders in France proved that there is a strong concern about the evaluation of research and teaching, and the institution's ability to win competitive grants and participate in various national calls. For the reason of improving the results of the competition, university leaders legitimate their activities and justify their decisions. Competition has driven HEIs into becoming competing organizations, and therefore the university leaders need to develop strategies to increase their performance impact (Espeland and Sauder, 2016).

The HEIs around the world are undergoing a rapid reform (Ntim, 2017). Following the trends ongoing in the world, the HEIs in Indonesia are also facing many challenges in terms of increasing the local and global competitors, increasing stakeholder pressure, decreasing government subsidies and increasing the demand for good governance. Society considers that the HEIs play a critical role because the institutions deal with three important missions, namely teaching, research and community service. As an interactive organization, the purpose of the HEIs is to directly and indirectly spread knowledge and to thus serve the community (Parker, 2013; Rowlands, 2013; de Haan, 2015; Ntim et al., 2017). Performance thus becomes an important issue because of the complex and unique characteristics of the HEIs (Rabovsky, 2014; Okwir, 2018). Unclear inputs, outputs and outcomes have increased the difficulties associated with good governance practices, especially in terms of performance measurement and the management system of the HEIs (Reponen, 1999; Czarniawska and Genell, 2002).

Scholars in developed countries have raised the issue of the importance of good governance in HEIs. For example, a study by Ntim et al. (2017) conducted in the UK revealed that there is a large degree of variability in the level of voluntary disclosure by universities, particularly regarding the disclosure of the teaching/research outcomes. Other studies have provided more empirical evidence related to the influence of other factors on the performance management system, such as behavioral factors (Elzinga, 2009), organizational factors (Mansor et al., 2012) and internal as well as external factors (Jelínková, 2017).

The performance management system is one of the important elements in a management control system that is also critical in good governance practices. A solid performance management system will guarantee the existence of good governance for the purpose of enhancing the competitive advantage present (Phiri and Tough, 2018). Unfortunately, many 
BIJ

27,6

1748

organizations still use a budget-based performance management system as a legacy of the past when the organization was still in the industrial era. The financial-based performance management system is, of course, important for managers to make decisions but it is insufficient when it comes to providing holistic information about organizational performance, especially when the organization is in the era of the knowledge economy. Scholars and practitioners have developed the strategic performance management as a solution to the problems caused by the financial or budget-based performance management system. The higher the competitive pressure, the higher the need for a reliable management control system as a part of good governance processes, specifically the SPM. Therefore, the following first hypothesis is proposed:

H1. Competitive pressure is positively associated with strategic performance management.

Both profit-oriented and not-for-profit organizations need to pay attention to their stakeholders because they influence the organizations' activities. Stakeholder demands good governance, meaning that they will put pressure on the management to have performance targets, a good strategy to achieve those targets and a reliable management control system, particularly SPM. Using a sample of Korean subsidiaries operating in China and Vietnam, Kim et al. (2018) confirmed the influence of stakeholders on the foreign subsidiaries' corporate social responsibility (CSR) practices. It also revealed that the impact of the stakeholders on performance is greater when the subsidiary enjoys greater autonomy. It is weaker when the host country is plagued with institutional voids.

The management of the HEIs show the same concerns about their stakeholders and vice versa. The main stakeholders consist of grant-giving institutions, government institutions, graduate recruiters (employers), university rating agencies, the parents of students and prospective students as well as alumni. Each group of stakeholders places a different pressure on the academics and university leaders. The academics compete with each other in a bid to secure funding for their research, and the competition for grants is also a competition for status (Musselin, 2018). Government concerns are related to the budget allocation and university status. Recruiters demand that the university should enhance the quality of its graduates. The parents and alumni demand that the university improve its education quality, image, costeffectiveness and good governance. To satisfy the interests of the stakeholders, the management of the HEIs need to have good corporate governance in which the management control system and SPM become the crucial elements. The higher the stakeholder pressure, the higher the need for a reliable management control system as a part of the good governance processes, specifically SPM. Therefore the second hypothesis is proposed:

H2. Stakeholder pressure is positively associated with the strategic performance management.

As stated by Porter (1986), the management needs to perform activities differently than their rivals do and they need to choose a different set of activities in order to deliver a unique mix of value. Competition and organizational strategy are thus found to be closely related (Gabrielsson et al., 2016; Pucciarelli and Kaplan, 2016; Bakoğlu et al., 2016; Slivko and Theilen, 2013; Dupire and M'Zali, 2016; Kadhim et al., 2018). In the era of competitive pressure, innovation capability becomes one of the strategic drivers of organizational performance. Oliva et al. (2019) conducted a study that analyzed the innovation process characteristics regarding the innovation types available. They suggested strategies for better knowledge management for each type of innovation in the main Brazilian business sectors. A study on the oil and gas industry in the UAE by Busaibe et al. (2017) revealed that a diverse management team improves the interactions between the employees and their leaders. It encourages innovation in order to address competition. In their study of the HEIs, Elkin et al. 
(2008) found that the business schools with a complete strategic focus had a higher level of current internationalization and greater aspirations for even higher levels of internationalization than the schools without a complete strategic focus. The higher the competitive pressure, the higher the need for a sound strategy in an organization. Therefore the third hypothesis is proposed:

H3. Competitive pressure is positively associated with strategy.

As stated by stakeholder theory, organizational performance relates to highly ethical relationships with the stakeholders characterized by high levels of trust, cooperation and information sharing (Donaldson and Preston, 1995; Schaltegger et al., 2017; Jones et al., 2018). Previous studies showed that there is a positive association between the stakeholders and strategy (Frooman, 1999; Sharma; Henriques, 2004; Nederhand and Klijn, 2017). Li et al. (2017) conducted a study using 26,400 Chinese firms in China and they proved that innovativeness is influenced strongly by its relationships to its o external stakeholders. Stakeholders demand that the management implement good governance in which organizational strategy is one of the important elements. In higher education, the students, employers, employees, alumni, parents, donors and government institutions demand that the management has a better level of performance than that of its rivals, therefore meaning that the management needs to have sound strategies to guarantee the interests of the stakeholder. The higher the stakeholder pressure, the higher the need for a good strategy in an organization. Therefore the fourth hypothesis is proposed:

H4. Stakeholder pressure is positively associated with strategy.

To formulate good strategy and effective execution, an organization needs good organizational knowledge which must be properly managed. As proven by Al Ahbabi et al. (2019), the knowledge management processes consist of knowledge creation, knowledge capture and storage, knowledge sharing and knowledge application. The aforementioned have a positive and significant impact on the operational, quality-based and innovation performance of the public sector in the UAE. SPM should also accommodate the human capital selection mechanism enabling managers to recruit the prospective human capital who come with functional personality traits that reduce knowledge hiding and workplace avoidance, in addition to augmenting task performance (Singh, 2019). SPM should provide a knowledge exchange mechanism as a critical tool for enhancing collective learning within an organization. Knowledge should be transferred for the purpose of effective collective learning (Singh et al., 2019b). As a part of management control, especially as a diagnostic tool, SPM is closely related to organizational strategy. Previous studies have explored the effect of strategy on the use of a management control system (Langfield-Smith, 1997; Henri, 2006; Otley, 2016). Arjaliès and Mundy (2013) conducted a study in French and provided evidence of the role of the levers of control in relation to enabling managers to identify and manage the threats and opportunities associated with CSR strategy, thus forming risk management processes that support the organizations in their attainment of the strategic objectives. A case study on Air Asia conducted by Adler et al. (2017) proved that strategy affects the design of performance management systems. The higher the need for a good strategy, the higher the need for a more strategic management control system, especially SPM. Therefore, the fifth hypothesis is proposed:

H5. Strategy is positively associated with strategic performance management system.

As previously discussed, competition is closely related to strategy. The management needs to focus on and prioritize a different set of activities in order to deliver a unique value (Porter, 1986; Elkin et al., 2008; Bagley and Portnoi, 2014; Gabrielsson et al., 2016; Ho and Peng, 2016; Pucciarelli and Kaplan, 2016; Bakoğlu et al., 2016; Slivko and Theilen, 2013; Dupire and
Mediating effect of strategy 
BIJ

27,6

1750
Figure 1.

Research framework

M'Zali, 2016; Kadhim et al., 2018). The increasing global competition in higher education requires the management of the HEIs to develop strategies focused on how to improve performance and consistently outperform other institutions. The higher the competitive pressure, the more important the role of a strategy in performance attainment is, thus meaning that the higher the need for a reliable management control system, specifically the SPM in achieving goal congruence. Therefore the sixth hypothesis is proposed:

H6. Strategy mediates the relationship between competitive pressure and a strategic performance management.

As previously discussed, stakeholders play an important role in influencing management activities. Each group of stakeholders has a specific interest that must be considered by the management; therefore, the stakeholders put pressure on the management. The higher the stakeholder pressure, the more important the role of strategy in accommodating the stakeholder's interests. Furthermore, the more important the role of strategy, the higher the need for a reliable management control, including SPM when achieving goal congruence (Donaldson and Preston, 1995; Schaltegger et al., 2017; Jones et al., 2018; Frooman, 1999; Sharma; Henriques, 2004; Li et al., 2017; Kim et al., 2018; Musselin, 2018). Therefore, the seventh hypothesis is proposed:

H7. Strategy mediates the relationship between stakeholder pressure and a strategic performance management.

Based on the literature review, the research framework of this study has been presented in Figure 1. This mediation model explains the mechanism of the relationships between the variables, namely (1) competitive pressure, (2) stakeholder pressure, (3) strategy and (3) the strategic performance management and the result of the mediation analysis is presented in Figure 2.

Figure 2.

Result of the structural model analysis
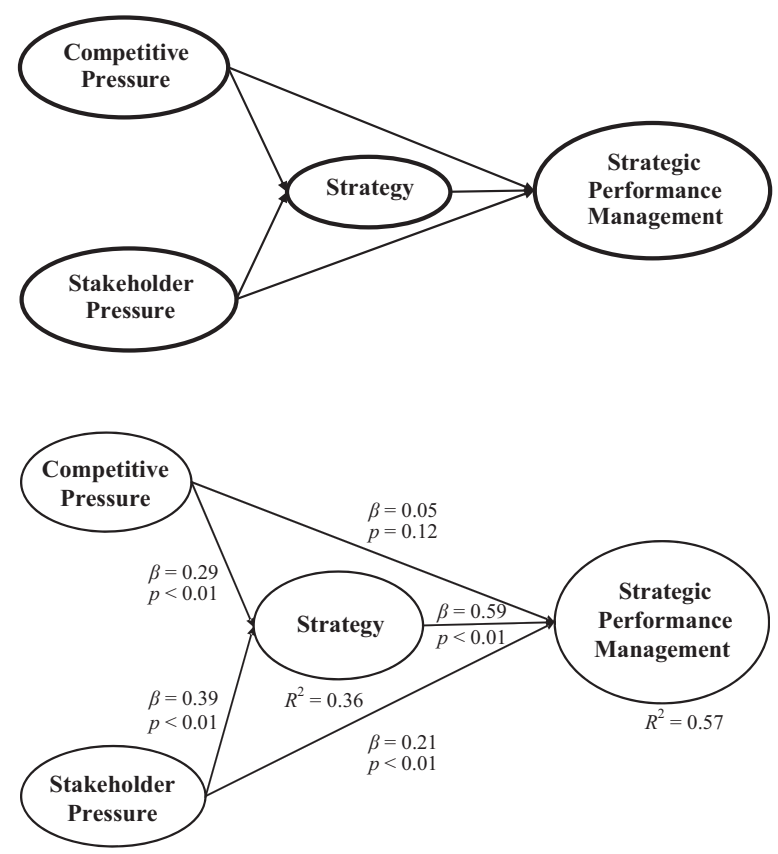


\section{Research methodology}

\subsection{Research design}

This study was designed as a quantitative research employing partial least square-structural equation modeling (PLS-SEM) to test the hypotheses. PLS-SEM is capable to handle multiple dependent and independent variables simultaneously. It does not require a normal distributional assumption and it is also widely applied in business and social sciences (Chin, 1998; Chin and Newsted, 1999). Therefore, PLS-SEM is suitable for this study.

\subsection{Data collection}

The MRTHE expects universities and institutes to have the capability to compete globally, therefore this study employs quota sampling to provide more opportunities to the managers of the universities and institutes. The population of the university and of the institute managers is also unknown. According to Sekaran and Bougie (2016:248), quota sampling can be used by taking into consideration the cost, time and need to adequately represent the minority elements in the population. As many as 1,000 questionnaires were distributed to all universities, institutes, higher schools/colleges, polytechnics and academies as shown in Table 1. A brief description of the study and the confidentiality assurance were also sent along with the questionnaire. The respondents were asked to return a completed

\begin{tabular}{lccc}
\hline Institutions & Questionnaires & Percentage & \\
\hline University & 586 & 58.6 & \\
Institute & 221 & 22.1 & \\
Academy & 70 & 7 & \\
Polytechnic & 48 & 4.8 & Table 1. \\
Higher School/College & 75 & 100 & Quota sampling \\
Total & 1,000 & & \\
\hline
\end{tabular}

\begin{tabular}{|c|c|c|c|}
\hline Description & Total & Percentage & \\
\hline \multicolumn{4}{|l|}{ Gender } \\
\hline Male & 414 & 75.8 & \\
\hline Female & 132 & 24.2 & \\
\hline Total & 546 & 100 & \\
\hline \multicolumn{4}{|l|}{ Education } \\
\hline Master & 279 & 51.1 & \\
\hline Doctoral & 267 & 48.9 & \\
\hline Total & 546 & 100 & \\
\hline \multicolumn{4}{|l|}{ Experiences } \\
\hline 1-5 years & 267 & 48.9 & \\
\hline $6-10$ years & 105 & 19.2 & \\
\hline$>10$ years & 174 & 31.9 & \\
\hline Total & 546 & 100 & \\
\hline \multicolumn{4}{|c|}{ Institutional form } \\
\hline University & 255 & 46.7 & \\
\hline Institute & 141 & 25.8 & \\
\hline Academy & 65 & 11.9 & \\
\hline Polytechnic & 40 & 7.3 & Table 2. \\
\hline Higher school & 45 & 8.3 & Characteristics of \\
\hline Total & 546 & 100 & respondents \\
\hline
\end{tabular}


BIJ

27,6

questionnaire within a week. The new questionnaire and a reminder letter were sent every month to those who had not returned the questionnaire. After 3 months, 182 managers had participated and after 6 months, as many as 546 managers had participated in the survey. The characteristics of the respondents are as shown in Table 2.

\subsection{Measurements of the constructs}

All of the variables were measured using instruments that were developed specifically for this study. Most of the previous questionnaires had been developed and used for research into profit-oriented companies and thus they are considered to be unsuitable for the HEI research setting. To measure the questionnaire items, a five-point Likert scale was used to rate from strongly disagree (1) to strongly agree (5).

Competitive pressure. Competitive pressure in this study is defined as the perception of the HEI managers regarding the forces regulating the competition within the higher education setting in Indonesia. The factors were measured using 10 items consisting of: (1) barriers to entry, (2) regulations, (3) competitive intensity in student recruitment, (4) more alternatives for prospective students to choose the HEI, (5) more similar study programs in the HEIs, (6) global standard orientation, (7) competitive intensity among the HEI leaders, (8) the increasing need for a clear positioning in the market, (9) competition with foreign HEIs and (10) competition with local HEIs.

Stakeholder pressure. Stakeholder pressure in this study is defined as the perception of managers of the HEIs regarding the external and internal forces that put pressure on the HEI management team. These factors were measured using 10 items consisting of the stakeholders from the following sources: (1) the President of the GOI, (2) the Ministry of Research, Technology and Higher Education of the GOI, (3) the House of Representatives of the GOI, (4) non-government organizations, (5) students and their parents, (6) the employers of graduates, (7) lecturers, (8) employees, (9) alumni and (10) other stakeholders.

Strategy. Strategy in this study is defined as the perception of the managers of the HEIs regarding the way to achieve the HEIs' vision and mission. These factors were measured using the 10 items of the strategy pillars consisting of (1) the importance of an increasingly clear and focused vision and mission, (2) the development of strategic themes, (3) strategic positioning from the perspective of the stakeholders, (4) the development of a clear competitive strategy, (5) the development of a competitive culture, (6) the alignment of functional strategies, (7) strategic alignment, both horizontally and vertically, (8) continuous strategic monitoring and feedback, (9) strategic communication and (10) strategic rewards.

Strategic Performance Management (SPM). The SPM of this study is defined as the perception of the managers of the HEIs regarding the existence of a performance management system that can help the management team to more effectively execute the organizational strategy. The existence of SPM was measured using 10 items consisting of (1) a more systematic and reliable management control system, (2) the development of strategic measures, such as key performance indicators, (3) the establishment of a special unit for managing organizational performance, (4) a special unit helping the leaders to monitor the strategic results, (5) a special unit helping the leaders with strategic communications, (6) a system for implementing strategic rewards and punishment, (7) SPM applications or software, (8) a periodic strategic results discussion among the management teams, (9) the implementation of specific methods such as that of Malcolm Balridge, the Balanced Scorecard and other approaches and (10) the development of human capital skills in the SPM implementation.

\section{Results and discussions}

\subsection{Results of descriptive statistics}

The results of the descriptive statistics have been presented in Table 3. The results show the following empirical findings. First, the mean value of $\mathrm{CP}$ is 4.389 , which indicated that the 
managers strongly agree with the questionnaire items of competitive pressure. This suggests that the HEI managers in Indonesia need to consider and adapt to the increasingly global competitive environment in higher education. The HEI managers in Indonesia need to improve the quality of the education provided when they have to compete for global resources and status. Second, the mean value of stakeholder pressure of 4.450 also suggests that the managers strongly agree with the questionnaire items of stakeholder pressure. This also suggests that the HEI managers in Indonesia need to consider and adapt to the increasing stakeholder interests in higher education. The stakeholders become more demanding and apply more pressure. Third, the mean value of strategy of 4.416 also suggests that the managers strongly agree with the questionnaire items on strategy. This indicates that the HEI managers are aware of the importance of developing and implementing a sound strategy. Finally, the mean value of SPM of 4.296 suggests that the managers strongly agree with the questionnaire items on SPM. This reveals the need for a better management control system in the HEIs studied, specifically a strategic performance management system.

\subsection{Measurement model analysis}

The reliability and validity of the measurements related to the specific constructs of this study were assessed using measurement model analysis. Following Kock (2016), WARP PLS 6.0 was used because it enables nonlinearity to be taken into consideration when estimating the coefficients of association among the linked variables.

In the first iteration, the measurement model analysis showed that there were indicators that are not valid (loading factor $<0.6)$ in competitive pressure $\left(\mathrm{CP}_{1}=0.465 ; \mathrm{CP}_{2}=0.345\right.$; $\mathrm{CP}_{6}=0.460 ; \mathrm{CP}_{9}=0.393$; and $\left.\mathrm{CP}_{10}=0.524\right)$, thus suggesting that barriers to entry, regulations, global standard orientation, competition with foreign HEIs and competition with local HEIs have not become relevant issues in the higher education competition in Indonesia at this time. Furthermore, another invalid indicator was stakeholder pressure $\left(\mathrm{SP}_{1}=0.443\right.$; $\mathrm{SP}_{4}=0.569 ; \mathrm{SP}_{6}=0.583$ ), suggesting that the president of the GOI, non-government organizations and the users of graduates have not become relevant issues within stakeholder pressure. The invalid indicators in organizational strategy $\left(\mathrm{ST}_{4}=0.435, \mathrm{ST}_{5}=0.569\right.$, $\left.\mathrm{ST}_{10}=0.315\right)$ suggest that the development of a clear competitive strategy, competitive culture and strategic rewards have not become relevant issues for organizational strategy. Finally, the invalid indicator in the SPM $\left(\mathrm{SPM}_{10}=0.476\right)$ suggests that the development of human capital skills in SPM implementation has not become a relevant issue in SPM at this time.

After the second iteration, Table 4 shows that all of the measures were significant and above the 0.60 loading level. This means that the measure accounts for at least $60 \%$ of the variance of the underlying latent variable (Chin, 1998). The composite reliability (CR) coefficients for the constructs are more than the accepted level of 0.70 , suggesting that the

\begin{tabular}{lcc}
\hline Constructs & Mean & Category \\
\hline Competitive Pressure & 4.389 & Strongly Agree \\
Stakeholder Pressure & 4.450 & Strongly Agree \\
Strategy & 4.416 & Strongly Agree \\
Strategic Performance Management System & 4.296 & Strongly Agree
\end{tabular}

Note(s): (1) interval = (highest score-lowest score / number of scores)

Interval $=(5-1) / 5=0.8$

(2) criteria of the average respondents' answers:

$1.00<\alpha<1.79$ : Strongly Disagree; $1.80<\alpha<2.59$ : Disagree; $2.60<\alpha<3.39$; Neutral: $3.40<\alpha<4.19$ : Agree; $4.20<\alpha<5.00$ : Strongly Agree
Mediating effect of strategy

1753 
BIJ
27,6

\begin{tabular}{|c|c|c|}
\hline Latent variable & Loading & $p$-values \\
\hline \multicolumn{3}{|c|}{ Competitive Pressure $\left(\right.$ Composite Reliability $=0.897^{(\mathrm{r})} ; A V E=0.634^{(c v)}$ ) } \\
\hline $\mathrm{CP} 3$ & 0.800 & $<0.001$ \\
\hline CP 4 & 0.768 & $<0.001$ \\
\hline CP 5 & 0.807 & $<0.001$ \\
\hline CP 7 & 0.841 & $<0.001$ \\
\hline $\mathrm{CP} 8$ & 0.765 & $<0.001$ \\
\hline \multicolumn{3}{|c|}{ Stakeholder Pressure (Composite Reliability $=0.863^{(r)} ; A V E=0.515^{(c v)}$ ) } \\
\hline SP 2 & 0.629 & $<0.001$ \\
\hline SP 3 & 0.625 & $<0.001$ \\
\hline SP 5 & 0.746 & $<0.001$ \\
\hline SP 7 & 0.783 & $<0.001$ \\
\hline SP 8 & 0.684 & $<0.001$ \\
\hline SP 9 & 0.817 & $<0.001$ \\
\hline \multicolumn{3}{|c|}{ Strategy $\left(\right.$ Composite Reliability $\left.=0.919^{(r)} ; A V E=0.621^{(c v)}\right)$} \\
\hline ST 1 & 0.722 & $<0.001$ \\
\hline ST 2 & 0.813 & $<0.001$ \\
\hline ST 3 & 0.684 & $<0.001$ \\
\hline ST 6 & 0.808 & $<0.001$ \\
\hline ST 7 & 0.814 & $<0.001$ \\
\hline ST 8 & 0.823 & $<0.001$ \\
\hline ST 9 & 0.840 & $<0.001$ \\
\hline \multicolumn{3}{|c|}{ Strategic Performance Management System (Composite Reliability $=0.930^{(r)} ; A V E=0.597^{(c)}$ ) } \\
\hline SPM 1 & 0.776 & $<0.001$ \\
\hline SPM 2 & 0.747 & $<0.001$ \\
\hline SPM 3 & 0.792 & $<0.001$ \\
\hline SPM 4 & 0.830 & $<0.001$ \\
\hline SPM 5 & 0.793 & $<0.001$ \\
\hline SPM 6 & 0.762 & $<0.001$ \\
\hline SPM 7 & 0.840 & $<0.001$ \\
\hline SPM 8 & 0.689 & $<0.001$ \\
\hline SPM 9 & 0.707 & $<0.001$ \\
\hline \multicolumn{3}{|c|}{$\begin{array}{l}\text { Note(s): }(1){ }^{(r)} \mathrm{CR} \text { of } 0.70 \text { or more: sufficient reliability } \\
(2)^{(\mathrm{cv})} \mathrm{AVE} \text { of } 0.50 \text { or more: convergent validity }\end{array}$} \\
\hline
\end{tabular}

measures are reliable (Nunnaly, 1967; Hair et al., 2013: 104). The construct validity was assessed using convergent validity and discriminant validity. To assess convergent validity, this study employed the average variance extracted (AVE). As shown in Table 4, the AVEs for all of the constructs were above 0.50. Following the work of Hulland (1999), this study provides evidence of convergent validity.

The discriminant validity was evaluated by comparing the square roots of the AVEs with the correlation between the constructs in order to describe whether a construct shares more variance with its measures than with the other constructs. When the square root of the AVE of a construct is greater than the correlation between the construct with another construct, it is valid (Fornell and Larcker, 1981). As shown in Table 5, a correlation between the constructs in the off-diagonal and the square root of AVE in the diagonal indicates adequate discriminant validity. This is because the diagonal elements were all greater than their respective off-diagonal elements. This proves that the measurement model is reliable and valid.

It can also be seen from Table 5 that competitive pressure has a positive and significant correlations with SPM $(r=0.417 ; p<0.001)$ and strategy $(r=0.488 ; p<0.001)$. This suggests that competitive pressure is an important variable in relation to improving the SPM 
as well as strategy. In addition, stakeholder pressure was also positively correlated with strategy $(r=0.536 ; p<0.001)$, indicating that stakeholder pressure may improve strategy. Finally, the table shows that strategy was also positively correlated with SPM $(r=0.726$; $p<0.001)$, revealing that strategy may enhance SPM.

\subsection{Structural model analysis}

This study focuses on testing (1) whether competitive pressure has a direct effect on strategic performance management system or if it is mediated by strategy and (2) whether stakeholder pressure has a direct effect on the strategic performance management system or if it is mediated by strategy. Following Baron and Kenny (1986) and Hair et al. (2011), the first step in testing the mediation model is to test the direct effect before inserting a mediating variable. The results from the direct effect must be significant. The results in Table 6 (Panel A) support the first hypothesis stating that competitive pressure is positively associated with strategic performance management system $\left(\beta=0.45 ; p<0.01 ; R^{2}=0.20\right)$. The second hypothesis

\begin{tabular}{|c|c|c|c|c|}
\hline & $\begin{array}{l}\text { Competitive } \\
\text { pressure }\end{array}$ & $\begin{array}{l}\text { Stakeholder } \\
\text { pressure }\end{array}$ & Strategy & $\begin{array}{c}\text { Strategic performance } \\
\text { management system }\end{array}$ \\
\hline Competitive Pressure & $0.796^{(\mathrm{dv})}$ & & & \\
\hline Stakeholder Pressure & $0.497^{* * * *}$ & $0.718^{(\mathrm{dv})}$ & & \\
\hline Strategy & $0.488 * * *$ & $0.536 * * *$ & $0.788^{(\mathrm{dv})}$ & \\
\hline $\begin{array}{l}\text { Strategic Performance } \\
\text { Management }\end{array}$ & $0.417 * * *$ & $0.533^{* * * *}$ & $0.726^{* * * *}$ & $0.772^{(\mathrm{dv})}$ \\
\hline
\end{tabular}

Note(s): (1) *** Significant at $p<0.01$

$(2)^{\text {(dv) }}$ discriminant validity: diagonal elements $>$ respective off-diagonal elements

Table 5. Discriminant validity

\begin{tabular}{llll}
\hline Panel A & $\beta$ coefficient & Probability & Decision \\
\hline
\end{tabular}

Before including strategy as the mediating variable

\begin{tabular}{lcll} 
Direct Effect & & & \\
CP $>$ SPM & 0.45 & $p<0.01$ & Significant, H1 is supported \\
SP $>$ SPM & 0.55 & $p<0.01$ & Significant, H2 is supported \\
\hline Panel B & $\beta$ Coefficient & Probability & Description \\
\hline
\end{tabular}

After including strategy as the mediating variable

Direct Effect

\begin{tabular}{llll} 
CP $>$ SPM & 0.05 & $p=0.12$ & Not significant \\
SP $>$ SPM & 0.21 & $p<0.01$ & Significant \\
CP $>$ S & 0.29 & $p<0.01$ & Significant, H3 is supported \\
SP $>$ S & 0.39 & $p<0.01$ & Significant, H4 is supported \\
S $>$ SPM & 0.59 & $p<0.01$ & Significant, H5 is supported \\
\hline
\end{tabular}

\begin{tabular}{lcll}
\hline Panel C & Indirect Effect & Probability & Decision \\
\hline Indirect effects & & & \\
CP $>$ S $>$ SPM & 0.174 & $<0.001 * * *$ & H6 is supported, full mediation \\
SP $>$ S $>$ SPM & 0.230 & $<0.001 * * *$ & H7 is supported, partial mediation
\end{tabular}

Note(s): (1) ***Significant at $p<0.01$

Table 6.

Summary of the structural model analysis 
BIJ

27,6

1756

stating that stakeholder pressure is positively associated with strategic performance management system is also supported $\left(\beta=0.55 ; p<0.01 ; R^{2}=0.31\right)$.

In the second step, strategy as the mediating variable was introduced. Table 6 shows the results of the structural model analysis. According to Hair et al. (2010:746), the following requirements of the mediating effects should be met: (1) the path coefficient from the independent variable to the dependent variable is significant, (2) the path coefficient from the independent variable to the intervening variable is significant and (3) the path coefficient from the intervening variable to the dependent variable is also significant. Before introducing strategy as a mediating variable, the path coefficient of $\mathrm{CP}>\mathrm{SPM}$ was found to be significant $(\beta=0.45 ; p<0.01)$. After introducing strategy, the path coefficient of CP > SPM was not significant $(\beta=0.05 ; p=0.12)$. This indicates that strategy fully mediates the relationship between competitive pressure and the strategic performance management system. Furthermore, before introducing strategy as the mediating variable, the path coefficient of $\mathrm{SP}>\mathrm{SPM}$ was significant $(\beta=0.55 ; p<0.01)$ and after introducing strategy, the path coefficient of SP $>$ SPM was still significant but with the smaller value $(\beta=0.21 ; p<0.01)$. This indicates that strategy partially mediates the relationship between competitive pressure and the strategic performance management system.

\subsection{Discussions}

This study provides empirical evidence of the antecedents of strategic performance management (SPM) as an important part of the management control system of the HEIs in Indonesia. The findings of the descriptive statistics suggest that the HEI managers in Indonesia strongly agree on the importance of the variables studied, consisting of competitive pressure, stakeholder pressure, strategy and strategic performance management. This result demonstrates the increasing awareness among the HEI managers regarding the impact of globalization on higher education in Indonesia. The fact that only three Indonesian universities were listed in the 500 Quacquarelli Symonds (QS) World University Ranking in 2018/2019 indicates that Indonesia is too late to act compared to the neighboring countries of Singapore and Malaysia.

The results of the measurement model analysis reveal that some of the indicators are not considered to be relevant measures of competitive pressure, stakeholder pressure, strategy, and SPM in Indonesia at this time. These indicators have a loading factor $<0.6$. The awareness of the HEI management in Indonesia regarding the dynamic changes in the global higher education environment and the WCU rankings is still in the early stage and has been within the last 5 years. Therefore some of those indicators are perceived as irrelevant by the managers of the HEIs.

The results of the structural model analysis demonstrate that all of the hypotheses are supported. As previously stated, the focus of this research is to analyze and test the mediating role of strategy in the competitive pressure-SPM relationship and in the stakeholder pressure-SPM relationship. Therefore, the results raise the following issues. First, having a sound strategy becomes a must for the HEIs. Good strategy formulation and execution must become the central issue when managing the HEIs in Indonesia in order to face the global competitive pressure, to meet the stakeholder expectations and to improve the university governance. Second, the empirical support for the competitive pressure-strategy relationship indicates that the HEI management in Indonesia has competitive behaviors and proceeded more strategically. This provides additional support for the previous studies in Europe, thus demonstrating that international rankings affect the university leaders (Hasse and Krucken, 2013; Musselin, 2018). Competitive behavior management has spread to Indonesia as a developing country. This confirms that there are new forms of competition in higher education all over the world, not only in terms of the competitive schemes involved but also in the nature of the competition itself. Third, the empirical support of the stakeholder pressure- 
strategy relationship indicates that the HEI management in Indonesia has adopted the concept of there being a market in higher education. This suggests that the management of the HEIs has to satisfy the different interests of each party in the market including the students, faculty and administrative staff, donors, government, parents, graduate recruiters, ranking institutions and other groups of stakeholders. Higher education is not considered to be a public good anymore. It has become a commodity, and therefore someone has to pay for the services provided. Lastly, the empirical support for the strategy-SPM relationship indicates that HEI management in Indonesia needs to design and implement a more reliable management control system, specifically SPM, in order to improve the good university governance. SPM will help the management of the HEIs to execute their strategies more effectively because it provides more comprehensive and strategic information for the purpose of decision-making. This will also facilitate the management of the HEIs so then they can have a better understanding of the fact that they need to be aware of improving their performance management. This is because they are now assessed and ranked based on more objective measures, quantitative indicators and algorithms than subjective evaluations. This also provides additional support for the previous studies (Reponen, 1999; Czarniawska and Genell, 2002; Phiri and Tough, 2018; Rabovsky, 2014; Okwir, 2018; Musselin, 2018).

\section{Conclusions, contributions and further research}

This study explores the mediation model of a research framework investigating whether both competitive pressure and stakeholder pressure have a direct effect on SPM and if so, whether the effect is mediated by strategy. The understanding of this association is important for both theoretical development and practical implications. Using a sample of $546 \mathrm{HEI}$ managers in Indonesia, this study demonstrates that both competitive pressure and stakeholder pressure are positively associated with SPM. Further analysis reveals that strategy fully mediates the competitive pressure-SPM relationship, and that strategy also partially mediates the stakeholder pressure-SPM relationship. This study explores one of the aspects in the work of Musselin (2018) stating that new forms of competition in higher education have improved the university governance by increasing the level of autonomy and introducing the management practices developed in private firms. This elaborates on the issue by analyzing and testing the role of strategy and SPM as the result of pressure from both competitors and stakeholders. Many studies have been conducted in developed countries, especially European universities, but only a few studies have investigated the issue in a developing country. This is the first study that explores the associations between competitive pressure, stakeholder pressure, strategy and SPM in Indonesian HEIs.

\subsection{Theoretical contributions}

All of the hypotheses of this study are supported. From the theoretical perspective, the result of this study provides empirical evidence for the following theoretical developments. First, it empirically supports the industry/organization model of competitive advantage, thus suggesting that the HEIs need to focus on the external factors in their strategies, especially competition and competitive pressure in the industry. In the context of Indonesian HEIs, this study contributes toward identifying the elements of competitive pressure, namely the level of competition in student recruitment, alternatives for students to choosing an HEI, the similarities between the study programs, competition among the HEI leaders, and the market positioning. Second, this study also supports stakeholder theory by identifying the elements of stakeholder pressure, namely the Ministry of Research, Technology and Higher Education, the House of Representatives, students and their parents, lecturers, employees, alumni and other stakeholders.
Mediating effect of strategy 
BIJ

27,6

Finally, this study also provides empirical evidence related to the resource-based model of competitive advantage, stating that the HEIs need to have unique assets, skills and capabilities including strategy and SPM. This study has identified the elements of strategy and the pillars that must be formulated and executed using SPM, namely a clear and focused vision and mission, strategic themes, strategic positioning, functional strategies, strategic alignment, monitoring and feedback, and strategic communication. Furthermore, this study has also revealed the elements of SPM that must be built by the managers of the HEIs, namely a management control system, strategic measures, a performance management unit, a monitoring unit for strategic results, strategic communications, a reward system, SPM applications or software, periodic strategic discussions and specific performance management methods.

The results of this study demonstrate that competitive pressure has a direct and positive effect on SPM and that stakeholder pressure has a direct and positive effect on SPM. Furthermore, the results prove that strategy fully mediates the competitive pressure-SPM relationship and that strategy partially mediates the stakeholder-SPM relationship. The results also provide additional supports for the previous works within higher education research conducted by many scholars (Reponen, 1999; Czarniawska and Genell, 2002; Elkin et al., 2008; Musselin, 2014, 2018; Espeland and Sauder, 2016; Ntim et al., 2017; Rabovsky, 2014; Bagley and Portnoi, 2014; Ho and Peng, 2016; Pucciarelli and Kaplan, 2016; Bakoğlu et al., 2016).

\subsection{Managerial implications}

From a practical point of view, this research model provides the following contributions. First, it provides a more comprehensive understanding for the managers of HEIs in Indonesia who want to enhance their SPM and organizational performance. The results of this study suggest that managers need to verify the role of strategy and its pillars in their institutions. Managers need to start from the dynamics of competitive pressure and the interests of the stakeholders when they develop their organizational strategies. This study proves that strategy and its pillars mediate the competitive pressure-SPM relationship as well as the stakeholder pressure-SPM relationship. Thus, the role of strategy must be prioritized by the HEI managers, including when related to knowledge management and open innovation in order to support good university governance. Second, the managers need to focus on the elements of competitive pressure, stakeholder pressure, strategy and SPM that have been identified in this study during the decision-making process. By prioritizing these elements, the managers can focus on the most important things that are fundamental in improving organizational performance. Finally, the managers should be aware that their HEIs are now being assessed using quantitative indicators, standardized processes and algorithms. Therefore, they should develop and implement a more reliable system of performance management derived from organizational strategy that has accommodated competitive pressure and stakeholder pressure.

\subsection{Contributions to society}

As the global competition increases in higher education all over the world, including in Indonesia, this research provides a model on how to improve good university governance involving strategy and SPM. Higher education plays an extremely important role in society. The better the HEIs' governance, the better the quality of life in a society in the knowledge economy era. This study provides a model that can be used by society to allow it to have better control of the HEIs by demanding improved good governance. This research model and the results provide empirical evidence of the importance of strategy and SPM. When the HEIs in Indonesia implement this model, the society will get more benefits in terms of 
improved transparency, accountability, fairness and the responsibility of the HEIs. The improved governance of the HEIs will ultimately improve their resource efficiencies and enhance the quality of higher education.

\subsection{Limitations and future research directions}

Although the findings of this study are significant in terms of both theoretical and practical developments, there are several limitations. First, the use of PLS-SEM may raise the issue of causality. Future studies should address this issue by using other approaches, such as an experiment or a case study to further validate the results. Second, this study focuses only on the antecedents of SPM. Future studies should investigate the consequences of the SPM on other variables such as the dysfunctional behavior of HEI managers, intellectual capital performance and university performance. It would be interesting to see the results if future studies use samples from a specific type of HEI, such as universities, academies, polytechnics or higher education schools to validate the results of the same model. Third, this study is context-specific to Indonesia and caution should be used when generalizing it to other countries. Finally, this study employs primary data which may raise the issue of perception bias. Future studies should try to develop proxies for the variables using secondary data. Notwithstanding the limitations, this study still provides additional theoretical and practical support to allow for a deeper understanding of how strategy plays an important role in the competitive pressure-SPM relationship as well as the stakeholder pressure-SPM relationship.

\section{References}

Adler, R., Stringer, C., Shantapriyan, P. and Birch, G. (2017), "AirAsia: towards a 'new world' carrier strategy and implications for performance management system design", in Harris, E. (Ed.), The Routledge Companion to Performance Management and Control, Routledge, Abingdon, pp. 319-333.

Al Ahbabi, S.A., Singh, S.K., Balasubramanian, S. and Gaur, S.S. (2019), "Employee perception of impact of knowledge management processes on public sector performance", Journal of Knowledge Management, Vol. 23 No. 2, pp. 351-373.

Albert, M. and Hildenbrand, A. (2016), "Industrial organization and experimental economics: how to learn from laboratory experiments", Homo Oeconomicus, Vol. 33 Nos 1-2, pp. 135-156.

Alexy, O., West, J., Klapper, H. and Reitzig, M. (2018), "Surrendering control to gain advantage: reconciling openness and the resource-based view of the firm", Strategic Management Journal, Vol. 39 No. 6, pp. 1704-1727.

Amor, M.B., Lindahl, M., Frankelius, P. and Hafedh Ben Abdennebi, H.B. (2018), "Revisiting industrial organization: product service systems insight", Journal of Cleaner Production, Vol. 196, pp. 1459-1477.

Annosi, M.C., Foss, N. and Brunetta, F. (2017), "The interaction of control systems and stakeholder networks in shaping the identities of self-managed teams”, Organization Studies, Vol. 38 No. 5 , pp. 619-645.

Arjaliès, D.L. and Mundy, J. (2013), "The use of management control systems to manage CSR strategy: a levers of control perspective”, Management Accounting Research, Vol. 24 No. 4, pp. 284-300.

Azeez, A.A. (2015), "Corporate governance and firm performance: evidence from Sri Lanka”, Journal of Finance and Bank Management, Vol. 3 No. 1, pp. 180-189.

Bagley, S.S. and Portnoi, L.M. (2014), "Setting the stage: global competition in higher education", New Directions for Higher Education, Vol. 2014 No. 168, pp. 5-11.

Bakoğlu, R., Öncer, A.Z., Yıldız, M.L. and Güllüoğlu, A.N. (2016), "Strategy development process in higher education: the case of marmara university", Procedia - Social and Behavioral Sciences, Vol. 235, pp. 36-45. 
BIJ

27,6

Barnett, M.L., Henriques, I. and Bryan, H.C. (2018), "Governing the void between stakeholder management and sustainability", Advances in Strategic Management, Vol. 38, pp. 121-143.

Barney, J. (1991), "Firm resources and sustained competitive advantage", Journal of Management, Vol. 17 No. 1, pp. 99-120.

Baron, R.M. and Kenny, D. (1986), "The moderator-mediator variable distinction in social psychological research: conceptual, strategic, and statistical considerations", Journal of Personality and Social Psychology, Vol. 51 No. 6, pp. 1173-1182.

Berenschot, W. and Mulder, P. (2019),"Explaining regional variation in local governance: clientelism and state-dependency in Indonesia”, World Development, Vol. 122, pp. 233-244.

Bhagat, S. and Bolton, B.J. (2009), "Sarbanes-oxley, governance and performance", Journal of Financial and Quantitative Analysis, Vol. 48 No. 1, pp. 105-135.

Bowman, E.H. and Helfat, C.E. (2001), "Does corporate strategy matter?", Strategic Management Journal, Vol. 22, pp. 1-23.

Budhwar, P., Pereira, V., Mellahi, K. and Singh, S.K. (2018), "The state of HRM in the Middle East: challenges and future research agenda", Asia Pacific Journal of Management, Vol. 36 No. 4, pp. 905-933.

Busaibe, L., Singh, S.K., Ahmad, S.Z. and Gaur, S.S. (2017), "Determinants of organizational innovation: a framework", Gender in Management, Vol. 32 No. 8, pp. 578-589.

Chatelain-Ponroy, S. and Morin-Delerm, S. (2012), "The sustainable development reporting: a new organizational practice in higher education institutions?", Paper Presented at 28th EGOS Colloquium Design !?, Jul 2012, Helsinki, Finland, p. 274, 2012, available at: https:/halshs. archives-ouvertes.fr/halshs-00712598/document.

Chesbrough, H. (2017), "The future of open innovation: the future of innovation is more extensive, more collaborative, and more engaged with a wider varietyof participants", ResearchTechnology Management, Vol. 60 No. 1, pp. 35-38.

Chin, W.W. and Newsted, P.R. (1999), "Structural equation modeling analysis with small samples using partial least squares", in Hoyle, R.H. (Ed.), Statistical Strategies for Small Sample Research, Sage Publications, Thousand Oaks, CA, pp. 307-341.

Chin, W.W. (1998), "The partial least squares approach to structural equation modeling”, in Marcoulides, G.A. (Ed.), Modern Methods for Business Research, Lawrence Erlbaum Associates, London.

Conner, K.R. (1991), "A historical comparison of resource-based theory and five schools of thought within industrial organization economics: do we have a new theory of the firm?", Journal of Management, Vol. 17 No. 1, pp. 121-154.

Cugueró-Escofet, N. and Rosanas, J.M. (2017), "The ethics of metrics: overcoming the dysfunctional effects of performance measurements through justice", Journal of Business Ethics, Vol. 140 No. 4, pp. 615-63.

Czarniawska, B. and Genell, K. (2002), "Gone shopping? Universities on their way to the market", Scandinavian Journal of Management, Vol. 18, pp. 455-474.

de Haan, H.H. (2015), "Competitive advantage, what does it really mean in the context of public higher education institutions?", International Journal of Educational Management, Vol. 29 No. 1, pp. 44-61.

Donaldson, T. and Preston, L.E. (1995), "The stakeholder theory of the corporation: concepts, evidence, and implications", Academy of Management Review, Vol. 20 No. 1, pp. 70-71.

Dupire, M. and MZali, B. (2016), "CSR strategies in response to competitive pressures", Journal of Business Ethics, Vol. 148 No. 3, pp. 603-623.

Elkin, G., Farnsworth, J. and Templer, A. (2008), "Strategy and the internationalisation of universities", International Journal of Educational Management, Vol. 22 No. 3, pp. 239-250. 
Elzinga, T., Albronda, B. and Kluijtmans, F. (2009), "Behavioral factors influencing performance management systems' use", International Journal of Productivity and Performance Management, Vol. 58 No. 6, pp. 508-522.

Espeland, W.N. and Sauder, M. (2016), Engines of Anxiety: Academic Rankings, Reputation, and Accountability, Russell Sage Foundation, New York.

Fiolleau, K., Libby, T. and Thorne, L. (2017), "Dysfunctional behavior in organizations: insights from the management control literature", AUDITING: A Journal of Practice and Theory, Vol. 37 No. 4, pp. 117-141.

Fornell, C. and Larcker, D.F. (1981), "Evaluating structural equation models with unobservable variables and measurement error", Journal of Marketing Research, Vol. 18 No. 1, pp. 39-50.

Frezatti, F., Bido, D.de S., Cruz, A.P.C. and Machado, M.J.C. (2017), "Impacts of interactive and diagnostic control system use on the innovation process", BAR-Brazilian Administration Review, Vol. 14 No. 3.

Friis, O., Holmgren, J. and Eskildsen, J.K. (2016), "A strategy model - better performance through improved strategy work", Journal of Modelling in Management, Vol. 11 No. 3, pp. 742-762.

Frooman, J. (1999), "Stakeholder influence strategies”, Academy of Management Review, Vol. 24 No. 2.

Gabrielsson, M., Seppälä, T. and Gabrielsson, P. (2016), "Realizing a hybrid competitive strategy and achieving superior financial performance while internationalizing in the high-technology market”, Industrial Marketing Management, Vol. 54, pp. 141-153.

Hair, J.F., Black, W.C., Babin, B.J. and Anderson, R.E. (2010), Multivariate Data Analysis, 7th ed., Prentice Hall International, New York.

Hair, J., Startstedt, M., Ringle, C. and Mena, J. (2011), "PLS SEM: indeed a silver bullet", Journal of Marketing Theory and Practice, Vol. 19 No. 2, pp. 139-151.

Hair, J.F., Black, W.C., Babin, B.J. and Anderson, R.E. (2013), Multivariate Data Analysis, 7th ed., Pearson Education.

Hasse, R. and Krucken, G. (2013), "Competition and actorhood: a further expansion of the neo-instituonal agenda”, Sociologia Internationalis, Vol. 51, pp. 181-205.

Hawawini, G., Subramanian, V. and Verdin, P. (2002), "Is performance driven by industry-or firmspecific factors? A new look at the evidence", Strategic Management Journal, Vol. 24 No. 1, pp. 1-16.

Henri, J.F. (2006), "Management control systems and strategy: a resource-based perspective", Accounting, Organizations and Society, Vol. 31, pp. 529-558.

Hernández-Perlines, F., Moreno-García, J. and Yañez-Araque, B. (2016), "The mediating role of competitive strategy in international entrepreneurial orientation", Journal of Business Research, Vol. 69 No. 11, pp. 5383-5389.

Ho, S.S.H. and Peng, M.Y.P. (2016), "Managing resources and relations in higher education institutions: a framework for understanding performance improvement", Educational Sciences: Theory and Practice, Vol. 16 No. 1, pp. 279-300.

Hosskisson, R.E., Hitt, M.A., Wan, W.P. and Yiu, D. (1999), "Swings of a pendulum: theory and research in strategic management", Journal of Management, Vol. 25, pp. 417-456.

Hulland, J. (1999), "Use of partial least squares (PLS) in strategic management research: a review of four recent study”, Strategic Management Journal, Vol. 20 No. 2, pp. 195-204.

Hussain, N., Rigoni, U. and Orij, R.P. (2018), "Corporate governance and sustainability performance: analysis of triple bottom line performance", Journal of Business Ethics, Vol. 149 No. 2, pp. 411-432.

Jambi-independent.co.id. (2019), "Jumlah Bahasa Daerah di Indonesia Meningkat”, available at: https:// www.jambi-independent.co.id/read/2019/10/25/44183/jumlah-bahasa-daerah-di-indonesiameningkat/ (accessed 20th March 2020). 
BIJ

27,6

1762

Jelínková, L. (2017), "Factors influencing the implementation and continuous improvement of the performance management system", presented at EBEEC Conference Proceedings, The Economies of Balkan and Eastern Europe Countries in the Changed World, KnE Social Sciences, pp. 242-256.

Jones, T.M., Harrison, J.S. and Felps, W. (2018), "How applying instrumental stakeholder theory can provide sustainable competitive advantage", Academy of Management Review, Vol. 43 No. 3, pp. 371-391.

Kadhim, R.I., Mohammed, M.A. and Gremikh, H.G. (2018), "Empowerment as a strategy to achieve the competitive advantage of organizations: a mediating role of organizational learning", Management Science Letters, Vol. 8, pp. 903-912.

Kaplan, R.S. and Norton, D.P. (2007), "Using the balanced scorecard as strategic management system", Harvard Business Review, Vol. 85 No. 7, pp. 75-85.

Kaur, S., Gupta, S., Singh, S.K. and Perano, M. (2019), "Organizational ambidexterity through global strategic partnerships: a cognitive computing perspective", Technological Forecasting and Social Change, Vol. 145, pp. 43-54.

Kim, C., Kim, J., Marshall, R. and Afzali, H. (2018), "Stakeholder influence, institutional duality, and CSR involvement of MNC subsidiaries", Journal of Business Research, Vol. 91, pp. 40-47.

Kock, N. (2016), "Advantages of nonlinear over segmentation analyses in path models", International Journal of E-Collaboration, Vol. 12 No. 4, pp. 1-6.

Langfield-Smith, K. (1997), "Management control systems and strategy: a critical review", Accounting, Organizations and Society, Vol. 22 No. 2, pp. 207-232.

Latan, H., Ringle, C.M. and Jabbour, C.J.C. (2016), "Whistleblowing intentions among public accountants in Indonesia: testing for the moderation effects", Journal of Business Ethics, Vol. 152 No. 2, pp. 573-588.

Latan, H., Jabbour, C.J.C. and de Sousa Jabbour, A.B.L. (2018). 'Whistleblowing triangle': framework and empirical evidence, Journal of Business Ethics, Vol. 160 No. 1, pp. 189-204.

Lazega, E. and Snijders, T.A. (2016), "Introduction”, in Lazega, E., Snijders, T.A. and Tom, A.B. (Eds), Multilevel Network Analysis for the Social Sciences, Springer, Cham, pp. 1-12.

Li, J., Xia, J. and Zajac, E.J. (2017), "On the duality of political and economic stakeholder influence on firm innovation performance: theory and evidence from Chinese firms”, Strategic Management Journal, Vol. 39 No. 1, pp. 193-216.

Mansor, N.N.A., Chakraborty, A.R., Yin, T.K. and Mahitapoglu, Z. (2012), "Organizational factors influencing performance management system in higher educational institution of south East Asia”, Procedia-Social and Behavioral Sciences, Vol. 40, pp. 584-590.

Marginson, S. (2006), "Dynamics of national and global competition in higher education", Higher Education, Vol. 52 No. 1, pp. 1-39.

Musselin, C. (2014), "Empowerment of French universities by funding and evaluation agencies" in, Organization Transformation and Scientific Change: The Impact of Institutional Restructuring on Universities and Intellectual Innovation, Emerald Group Publishing, Bingley, pp. 51-76.

Musselin, C. (2018), "New forms of competition in higher education", Socio-Economic Review, Vol. 16 No. 3, pp. 657-683.

Mutlu, C.C., Essen, M.V., Peng, M.W., Saleh, S.F. and Duran, P. (2018), "Corporate governance in China: a meta-analysis", Journal of Management Studies, Vol. 55 No. 6, pp. 943-979.

Nederhand, J. and Klijn, E.H. (2017), "Stakeholder involvement in public-private partnerships: its influence on the innovative character of projects and on project performance", Administration and Society, Vol. 51 No. 8, pp. 1-27.

Newbert, S.L. (2008), "Value, rareness, competitive advantage, and performance: a conceptual-level empirical investigation of the resource-based view of the firm", Strategic Management Journal, Vol. 29 No. 7, pp. 745-768. 
Nicholson, G.J. and Kiel, G.C. (2007), "Can Directors Impact Performance? A case-based test of three theories of corporate governance", Corporate Governance: An International Review, Vol. 15 No. 4, pp. 585-608.

Ntim, C.G., Soobaroyen, T. and Broad, M.J. (2017), "Governance structures, voluntary disclosures and public accountability: the case of UK higher education institutions", Accounting, Auditing \& Accountability Journal, Vol. 30 No. 1, pp. 65-118.

Nunnaly, J.C. (1967), Psychometric Theory, McGraw-Hill, New York.

Okwir, S., Nudurupati, S.S., Ginieis, M. and Angelis, J. (2018), "Performance measurement and management systems: a perspective from complexity theory", International Journal of Management Reviews, Vol. 20 No. 3.

Oliva, F.L., Semensato, B.I., Prioste, D.B., Winandy, E.J.L., Bution, J., Couto, M.C., Bottacin, M.A., Ferranty, L., Teberga, P.M.F., Santos, R.F.S., Singh, S., Silva, S.F. and Massaini, S.A. (2019), "Innovation in the main Brazilian business sectors: characteristics, types and comparison of innovation", Journal of Knowledge Management, Vol. 1 No. 23, pp. 135-175.

Otley, D. (1999), "Performance management: a framework for management control systems research", Management Accounting Research, Vol. 10 No. 4, pp. 363-382.

Otley, D. (2016), "The contingency theory of management accounting and control: 1980-2014", Management Accounting Research, Vol. 31, pp. 45-62.

Parker, L.D. (2013), "Contemporary university strategising: the financial imperative”, Financial Accountability and Management, Vol. 29 No. 1, pp. 1-25.

PDDIKTI. (2019), “Grafik jumlah perguruan tinggi”, available at: https://forlap.ristekdikti.go.id/ perguruantinggi/homegraphpt (accessed 10 March 2019).

Penrose, E. (1959), The Theory of the Growth of the Firm, John Wiley, New York, NY.

Phiri, M.J. and Tough, A.G. (2018), "Managing university records in the world of governance", Records Management Journal, Vol. 28 No. 1, pp. 47-61.

Popli, M., Ladkani, R.M. and Gaur, A.S. (2017), "Business group affiliation and post-acquisition performance: an extended resource-based view", Journal of Business Research, Vol. 81, pp. 21-30.

Porter, M.E. (1986), "What is strategy?”, Harvard Business Review, Vol. 74 No. 6, pp. 61-78.

Pucciarelli, F. and Kaplan, A. (2016), "Competition and strategy in higher education: managing complexity and uncertainty", Business Horizons, Vol. 59 No. 3, pp. 311-320.

Rabovsky, T.M. (2014), "Using data to manage for performance at public universities", Public Administration Review, Vol. 74 No. 2, pp. 260-272.

Reponen, T. (1999), "Is leadership possible at loosely coupled organizations such as universities?", Higher Education Policy, Vol. 12 No. 4, pp. 237-244.

Rosenbusch, K. (2020), "Technology intervention: rethinking the role of education and faculty in the transformative digital environment", Advances in Developing Human Resources, Vol. 22 No. 1, pp. 87-101.

Rowlands, J. (2013), “Academic boards: less intellectual and more academic capital in higher education governance?”, Studies in Higher Education, Vol. 38 No. 9, pp. 1274-1289.

Schaltegger, S., Hörisch, J. and Freeman, R.E. (2017), "Business cases for sustainability: a stakeholder theory perspective", Organization and Environment, Vol. 12, pp. 1-22.

Sekaran, U. and Bougie, R. (2016), Research Methods for Business: A Skill-Building Approach, 7th ed., John Wiley and Sons, Chichester, West Sussex.

Sharma, S. and Henriques, I. (2004), "Stakeholder influences on sustainability practices in the Canadian forest products industry", Strategic Management Journal, Vol. 26 No. 2, pp. 97-195.

Simons, R. (1991), "Strategic orientation and top management attention to control systems", Strategic Management Journal, Vol. 12 No. 1, pp. 49-62. 
BIJ

27,6

Singh, S.K., Gupta, S., Busso, D. and Kamboj, S. (2019a), "Top management knowledge value, knowledge sharing practices, open innovation and organizational performance", Journal of Business Research, doi: 10.1016/j.jbusres.2019.04.040.

Singh, S.K., Mittal, S., Sengupta, A. and Pradhan, R.K. (2019b), "A dual-pathway model of knowledge exchange: linking human and psychosocial capital with prosocial knowledge effectiveness", Journal of Knowledge Management, Vol. 23 No. 5, pp. 889-914.

Singh, S.K. (2019), "Territoriality, task performance, and workplace deviance: empirical evidence on role of knowledge hiding", Journal of Business Research, Vol. 97, pp. 10-19.

Slaughter, S. and Leslie, L.L. (1997), Academic Capitalism: Politics, Policies, Entrepreneurial University, The Johns Hopkins University Press, Baltimore.

Slivko, O. and Theilen, B. (2013), "Innovation or imitation? The effect of spillovers and competitive pressure on firms' R\&D strategy choice”, Journal of Economics, Vol. 112 No. 3, pp. 253-282.

Soobaroyen, T. (2005), "Management control systems and dysfunctional behavior: an empirical investigation", AAA Management Accounting Section 2006 Meeting Paper, SSRN: available at: https://ssrn.com/abstract $=771304$.

Taylor, B.J., Webber, K.L. and Jacobs, G.J. (2013), "Institutional research in light of internationalization: growth, and competition", New Directions for Institutional Research, Vol. 157, pp. 5-22.

United Nations. (1982), "United Nations convention on the law of the sea, 10 december 1982", available at: https://www.un.org/depts/los/convention_agreements/texts/unclos/unclos_e.pdf (accessed 20th March 2020).

Welianto, A. (2020), "Daftar Suku Bangsa di Indonesia”, available at: https://www.kompas.com/skola/read/ 2020/01/04/210000869/daftar-suku-bangsa-di-indonesia?page=all (accessed 19th March 2020).

Wernerfelt, B. (1984), “A resource-based view of the firm”, Strategic Management Journal, Vol. 5 No. 2 , pp. $71-180$.

Wernerfelt, B. (1995). "The resource-based view of the firm: ten years after", Strategic Management Journal, Vol. 16 No. 3, pp. 169-250.

\begin{abstract}
About the authors
Noorlailie Soewarno, Faculty of Economics and Business, Universitas Airlangga, Surabaya, Indonesia is a Doctor of Accounting at Faculty of Economics and Business Universitas Airlangga, Surabaya, Indonesia. She has been teaching accounting for more than 20 years. Her research interest including management accounting, strategic management, and performance management.

Bambang Tjahjadi, Faculty of Economics and Business Universitas Airlangga, Surabaya, Indonesia, Bambang Tjahjadi is a professor of accounting at Faculty of Economics and Business Universitas Airlangga, Surabaya, Indonesia. He has been teaching accounting for more than 30 years. His research interest including management accounting, strategic management, and performance management. Bambang is a member of professional organization such as Certified Professional Marketers and Certified Management Accountant. Bambang Tjahjadi is the corresponding author and can be contacted at: bambang.tjahjadi@feb.unair.ac.id
\end{abstract}

For instructions on how to order reprints of this article, please visit our website:

www.emeraldgrouppublishing.com/licensing/reprints.htm

Or contact us for further details: permissions@emeraldinsight.com 